\title{
SENAM HIPERTENSI TERHADAP PENURUNAN TEKANAN DARAH PADA LANSIA DI WILAYAH KERJA PUSKESMAS BONTONYELENG
}

\author{
${ }^{1}$ Zatul Haefa \\ ${ }^{2}$ Hamdana \\ ${ }^{3}$ Amirullah
}

1Program Studi S1 Keperawatan Stikes Panrita Husada Bulukumba,Indonesia ${ }^{2}$ Departemen Keperawatan Medikal Bedah, Stikes Panrita Husada Bulukumba, Indonesia

${ }^{3}$ Departemen Keperawatan Medikal Bedah, Stikes Panrita Husada Bulukumba, Indonesia

\author{
Alamat Koresponden: \\ Zatul Haefa \\ Annie, Desa Bukit Harapan \\ Kecamatan Gantarang, Kabupaten Bulukumba \\ Hp. 082393059944 \\ Email:zatulhaefa30@gmail.com
}




\begin{abstract}
ABSTRAK
Lanjut usia adalah tahap akhir perkembangan pada daur kehidupan manusia. Pada lansia terjadi penurunan anatomik dan fungsi dari organ-organ. Penurunan fungsi pada pembuluh darah dapat mengakibatkan hipertensi. Hipertensi atau tekanan darah tinggi adalah suatu keadaan dimana ketika tekanan darah di pembuluh darah meningkat, dengan hasil pengukuran $140 / 90 \mathrm{mmHg}$. Salah satu yang mempengaruhi penurunan hipertensi tanpa obat-obatan yaitu olahraga yang tidak terlalu berat secara teratur seperti senam hipertensi. Senam hipertensi atau senam lansia adalah suatu bentuk olahraga aerobik yang bermanfaat bagi para lanjut usia. Senam lansia yang teratur dapat membantu menjaga keseimbangan tekanan darah. Tujuan Penelitian untuk mengetahui pengaruh senam hipertensi terhadap penurunan tekanan darah pada lansia di wilayah kerja Puskesmas Bontonyeleng. Rancangan penelitian ini menggunakan rancangan penelitian pra eksperiment (One-group pre-post test design) didapatkan jumlah sampel 30 orang dengan menggunakan teknik pengambilan sampel yaitu Nonprobability sampling denganpendekatansampling incidental. Hasil uji normalitas menunjukkan data tidak berdistribusi nomal sehingga tidak memenuhi uji T berpasangan dan digunakan uji alternatif yaitu uji wilcoxon. Didapatkan nilai $\mathrm{p}$ value yaitu $0,000(\mathrm{p}<0,05)$ pada tekanan darah sistolik dan diastolik maka Ho ditolak dan Ha diterima. Dapat disimpulkan bahwa terdapat pengaruh senam hipertensi terhadap penurunan tekanan darah sistolik dan diastolik pada lansia di wilayah kerja Puskesmas Bontonyeleng. Dan disarankan untuk adanya informasi tentang hipertensi dan lebih meningkatkan frekuensi senam pada lansia minimal 2-3 kali seminggu untuk mendapatkan hasil yang lebih baik.
\end{abstract}

Kata Kunci : Tekanan Darah Lansia, Senam Hipertensi.

\begin{abstract}
Elderly is the final stage of development in the human life cycle. In the elderly there is an anatomic decline and function of the organs. Decreased function of blood vessels can cause hypertension. Hypertension or high blood pressure is a condition where when the blood pressure in the blood vessels increases, the measurement results are 140/90 mmHg. One that affects the reduction in hypertension without drugs is exercise that is not too heavy on a regular basis such as hypertension gymnastics. Hypertension or elderly exercise is a form of aerobic exercise that is beneficial for the elderly. Regular elderly exercise can help maintain blood pressure balance. The purpose of this study was to determine the effect of hypertension exercise on reducing blood pressure in the elderly in the work area of the Bontonyeleng Health Center. The design of this study used a pre-experimental research design (One-group pre-post test design) obtained a sample of 30 people by using a sampling technique that is Nonprobability sampling with incidental sampling approach. The results of the normality test show that the data are not distributed so that they do not meet the paired $T$ test and an alternative test is used is the Wilcoxon test. $P$ value obtained is $0,000(p<0.05)$ on systolic and diastolic blood pressure, so Ho is rejected and $\mathrm{Ha}$ is accepted. It can be concluded that there is an effect of hypertension gymnastics on the decrease in systolic and diastolic blood pressure in the elderly in the work area of the Bontonyeleng Health Center. And it is advisable to have information about hypertension and further increase the frequency of exercise in the elderly at least 2-3 times a week to get better results.
\end{abstract}

Keywords: Elderly Blood Pressure, Hypertension Gymnastics. 


\section{PENDAHULUAN}

Hipertensi atau tekanan darah tinggi adalah suatu keadaan dimana ketika tekanan darah di pembuluh darah meningkat, dengan hasil pengukuran 140/90 mmHg. Hipertesi adalah salah satu peyebabab utama kematian dini diseluruh dunia dimana hipertensi membunuh hampir 8 miliyar orang setiap tahun di dunia (Suprapto, 2014). Sekitar 1,56 miliar orang dewasa akan menderita hipertesi di tahun 2020 dan hampir 1,5 juta orang setiap tahun di kawasan Asia TimurSelatan, dan diwilayah Asia Tenggara termasuk Indonesia insiden kasus hipertensi juga meningkat sebanyak $28 \%$.

Hasil Riskesdas pada tahun 2013 prevalensi hipertensi di Sulawesi Selatan sebesar 28,1 persen, dengan nilai tertinggi di Enrekang (31,3\%), diikuti Bulukumba $(30,8 \%)$, Sinjai $(30,4 \%)$ dan Gowa $(29,2 \%)$ yang didapat melalui pengukuran tekanan darah pada umur 18 tahun keatas. Sedangkan yang didapat melalui kuesioner yang didiagnosis tenaga kesehatan sebesar 10,3\%, yang didiagnosis tenaga kesehatan atau yang sedang minum obat sebesar $10,5 \%$,sehingga terdapat $0,2 \%$ yang minum obat sendiri. Berdasarkan data yang diperoleh di wilayah kerja puskesmas Bontonyeleng terjadi peningkatan penyakit hipertensi satu tahun terakhir, tercatat pada tahun 2016 penderita hipertensi sebanyak
181 orang, sedangkan pada tahun 2017 berjumlah 598 orang. Pasien lansia umur $\geq$ 45 yang berkunjung dan memeriksakan kesehatannya satu tahun terakhir terdapat 419 dengan pasien berulang.

Tujuan penelitian ini adalah untuk mengetahui apakah ada pengaruh senam hipertensi terhadap penurunan tekanan darah sistolik dan diastolik pada lansia di wilayah kerja Puskesmas Bontonyeleng.

\section{METODE}

Jenis penelitian ini menggunakan penelitian Pre-eksperimental design dengan rancangan penelitian One group Pretest-Posttest Design pada desain ini terdapat pretest, sebelum dilakukan perlakuan, demikian hasil perlakuan dapat diketahui lebih akurat, karena dapat membandingkan dengan keadaan sebelum diberi perlakuan .Pretest-Posttest Design penelitian ini dilakukan dengan cara memberikan Pretest (pengamatan awal) terlebih dahulu sebelum diberikan intervensi, setelah itu diberikan intervensi, berupa senam hipertensi, kemudian dilakukan Posttest (pengamatan akhir) (Sugiyono, 2012). Pemberian senam lansia kepada responden yang mengalami hipertensi dilakukan 40 menit sebanyak 3 kali dalam 1 minggu. Populasi dalam penelitian adalah sekelompok subyek dengan karakteristik tertentu. Populasi dalam penelitian ini adalah penderita 
hipertensidi wilayah kerja puskesmas Bontonyeleng sebanyak 598 orang (Riskesdas, 2013)

Tekhnik pengambilan sampel pada penelitian ini nonprobability sampling. Nonprobability sampling dengan pendekatan sampling incidental. Sampling incidental adalah teknik penentuan sampel berdasarkan kebetulan, yaitu siapa saja yang secara kebetulan/incidental bertemu dengan peneliti dapat digunakan sebagai sampel, bila dipandang orang yang kebetulan ditemui itu cocok sebagai sumber data . Jumlah sampel dalam penelitian ini adalah 30 responden yang rutin mengikuti kegiatan senam (Notoatmojo, 2012).

Instrumen dalam penelitian ini adalah observasi (pengamatan). Observasi merupakan cara pengumpulan data dengan mengadakan melakukan pengamatan secara langsung kepada responden penelitian untuk mencari perubahan atau hal-hal yang akan diteliti.Dalam metode observasi ini, instrumen yang dapat digunakan, adalah lembar observasi, paduan pengamatan (observasi), atau lembar checklist (Sugiyono,2012).

Data dianalisis berdasarkan skala ukur dan tujuan penelitian dengan menggunakan perangkat lunak program komputerisasi.Data dianalisis secara : (1). Analisis Univariat adalah analisis yang dilakukan untuk menganalisis variabel. (2).
Analisis Bivariat, Penelitian analisa bivariat adalah analisa yang dilakukan lebih dari dua variabel (Notoadmodjo, 2012). Analisa bivariat berfungsi mengetahui hubungan antar variabel. Analisis bivariat dalam penelitian ini adalah mengetahui pengaruh senam hipertensi terhadap penurunan tekanan darah pada lansia dengan melihat pretest dan posttest. Analisa ini menggunakan uji statistik uji t-berpasangan dan uji alternatif yaitu uji Wilcoxon (Sastroasmoro, 2014).

\section{HASIL}

Berdasarkan tabel 1 bahwa sebagian besar yang menderita hipertensi di wilayah kerja Puskesmas Bontonyeleng Kabupaten Bulukumba, berdasarkan kriteria jenis kelamin yaitu laki-laki sebanyak 9 responden $(30,0 \%)$ sedangkan jenis kelamin perempuan 21 responden $(70,0 \%)$ lebih banyak di bandingkan dengan yang berjenis kelamin laki-laki. Berdasarkan kriteria umur usia pertengahan yaitu sebanyak 21 responden $(70,0 \%)$, sedangkan kriteria umur lanjut usia yaitu sebanyak 9 responden $\quad(30,0 \%)$ Berdasarkan latar belakang pendidikan yang terbanyak yaitu SD sebanyak 15 responden $(53,3 \%)$ dan yang terendah adalah SMA dan S1 sebanyak 2 responden $(6,7 \%)$. Berdasarkan kriteria pekerjaan sebagian besar adalah Ibu rumah tangga sebanyak 18 responden $(60,0 \%)$, dan yang 
terendah adalah wiraswasta dan guru sebanyak 2 responden $(6,7 \%)$.

Berdasarkan tabel 2 distribusi frekuensi tekanan darah sistol sebelum senam yaitu semua responden memiliki kriteria tekanan darah tinggi sebanyak 30 responden. Distribusi frekuensi tekanan darah sistol setelah senam yaitu dari 30 responden kriteria tekanan darah tinggi sebanyak 8 responden $(26,7 \%)$, sedangkan kriteria normal sebanyak 22 responden $(73,3 \%)$.

Berdasarkan Tabel 3, Distribusi frekuensi tekanan darah diastol sebelum senam yaitu 29 responden $(96,7 \%)$ memiliki kriteria tekanan darah tinggi dan 1 responden $(3,3 \%)$ dalam keadaan normal. Ddistribusi frekuensi tekanan darah diastol setelah senam yaitu 5 responden $(16,7 \%)$ memiliki kriteria tekanan darah tinggi dan 25 responden $(83,3 \%)$ dalam keadaan normal.

Dari hasil uji normalitas data dengan menggunakan metode analisis didapatkan nilai shapiro wilk pada variabel pretestsenam sebesar $0,000(\mathrm{p}<0,05)$ dan variabel posttestsenam sebesar 0,000 $(\mathrm{p}<0,05)$, sehingga dapat dikatakan bahwa sebaran data tidak normal. Sehingga syarat untuk diuji T-berpasangan tidak terpenuhi. Dan digunakan uji alternatif uji wilcoxon.

Berdasarkan tabel 4 menunjukkan bahwa tekanan darah sistolik pada lansia sebelum senam yaitu 30 responden $(100 \%)$ dalam keadaan tekanan darah tinggi dan setelah diberikan intervensi/perlakuan 8 responden $(26,7 \%)$ mengalami penurunan tekanan darah. Dengan menggunakan Uji t berpasangan/paired-samples test alternatif Wilcoxon didapatkan nilai $\mathrm{p}=0,00$ dengan kata lain ada pengaruh senam hipertensi terhadap penurunan tekanan darah sistolik pada lansia di wilayah kerja Puskesmas Bontonyeleng Tahun 2018 sedangkan dari 30 responden, tekanan darah diastolik pada lansia sebelum diberikan perlakuan/intervensi 29 responden $(96,7 \%)$ dalam keadaan tekanan darah tinggi dan 1 responden $(3,3 \%)$, sedangkan tekanan darah setelah perlakuan yaitu 5 responden $(16,7 \%)$ yang tidak mengalami penurunan dan 25 responden $(83,3 \%)$ dalam keadaan normal. Hasil uji $\mathrm{t}$ berpasangan/pairedsamples test alternatif Wilcoxondidapatkan nilai $\mathrm{p}=0,00$ yang berarti ada pengaruh senam hipertensi terhadap penurunan tekanan darah diastolik pada lansia di wilayah kerja Puskesmas Bontonyeleng Tahun 2018.

\section{PEMBAHASAN}

Pada hasil penelitian dari 30 jumlah responden, setelah dilakukan observasi dengan menggunakan spignomanometer dan stetoskop pada pengukuran tekanan darah. Hasil pengukuran sistolik kategori tinggi sebanyak 30 responden (100\%). Sedangkan kategori tekanan darah normal 
tidak ada, sebelum diberikan intervensi atau perlakuan berupa senam hipertensi. Sedangkan untuk diastolik yaitu terdapat 29 responden $(6,7 \%)$ dalam keadaan tekanan darah tinggi dan 1 responden $(3,3 \%)$ dalam keadaan normal .

Untuk mengetahui ada tidaknya pengaruh senam hipertensi terhadap penurunan tekanan darah pada lansia di wilayah kerja Puskesmas Bontonyeleng sebelum dan setelah diberikan perlakuan/intervensi, dilakukan uji wilcoxon. Berawal dari hipotesis penelitian, Ho: tidak ada pengaruh senam hipertensi terhadap penurunan tekanan darah pada lansia di wilayah kerja Puskesmas Bontonyeleng. Dan Ha: ada pengaruh senam hipertensi terhadap penurunan tekanan darah pada lansia di wilayah kerja Puskesmas Bontonyeleng.

Tingkat signifikan yang dipergunakan pada uji wilcoxon adalah $\alpha=5 \%$ dengan nilai signifikan adalah 0,00 . Kriteria pengujian yang digunakan adalah HOditerima jika nilai signifikan > 0,05 dan Ho ditolak jika nilai signifikan $<0,05$. Nilai signifikan yang didapatkan adalah p-value $0,00<\alpha 0,05$, maka Ho ditolak maka peneliti berkesimpulan ada perbedaan proporsi sebelum dan setelah diberikan perlakuan/intervensi berupa senam hipertensi.

Hasil penelitian dapat dilihat pada tabel 5.6 perbedaan tekanan sistolik sebelum yaitu semua 30 responden dalam keadaan tinggi, dan setelah diberikan perlakuan/intervensi 22 responden $(73,3 \%)$ mengalami penurunan dan 8 responden $(26,7 \%)$ tidak mengalami penurunan. Sedangkan pada tabel 5.7 yaitu perbedaan tekanan darah diastolik sebelum menunjukkan 29 responden $(6,7 \%)$ dalam keadaan tekanan darah tinggi dan 1 responden $(3,3 \%)$ dalam keadaan normal setelah intervensi 5 responden $(16,7 \%)$ dalam keadaan tinggi dan 25 responden $(83,3 \%)$ mengalami penurunan. Dapat disimpulkan responden yang mengalami penurunan tekanan darah karena benarbenar mengikuti prosedur dan gerakangerakan senam dengan baik, sedangkan responden yang tidak mengalami penurunan diakibatkan karena responden kurang aktif dalam gerakan-gerakan senam.

Menurut berbagai upaya dilaksanakan oleh pemerintah, diantaranya pelayanan kesehatan, sosial, ketenagakerjaan, dan lainya yang telah dikerjakan pada berbagai tingkatan, yaitu individu lansia, kelompok lansia, keluarga, Panti Sosial Tresna Wreda (PSTW), Sarana pelayanan kesehatan tingkat dasar (primer), tinkat pertama (sekunder), dan tingkat lanjut (tersier) untuk mengatasi permasalahan lansia.

Menurut teori olahraga secara teratur di anjurkan untuk penderita hipertensi 
karena olahraga terbukti dapat merombak lemak yang berbahaya dan dapat menghindari terjadinya penimbunan lemak di dinding pembuluh darah. Apabila penderita hipertensi jarang melakukan olahraga maka penimbunan lemak di dinding pembuluh darah tidak dapat dihindari, akibatnya terjadi peningkatan tekanandarah (hipertensi) (Pamungkas, 2016).

Berdasarkan penelitian yang dilakukan dapat diketahui nilai $p$ value adalah 0,001 yang berarti terdapat pengaruh senam lansia terhadap tekanan darah diastol pada lansia penderita hipertensi di Posyandu Lansia Wotgaleh karena nilai $p$ value kurang dari 0,05. Pemberian senam lansia kepada responden yang mengalami hipertensi dilakukan 40 menit sebanyak 3 kali dalam 1 minggu. Dari 32 lansia penderita hipertensi semua memenuhi kriteria inklusi dan tidak ada yang drop out. Hasil penelitian tersebut menunjukkan bahwa semua responden mengalami penurunan tekanan darah dikarenakan mereka aktif mengikuti gerakan senam dan mengikuti prosedur senam yang benar secara berkontinuitas yaitu melakukan latihan pemanasan, latihan inti serta latihan pendinginan atau latihan penutup. Penelitian tersebut

Menurut asumsi peneliti terkait hasil penelitian yang didapatkan bahwa penurunan tekanan darah dipengaruhi oleh beberapa faktor, yaitu dengan melakukan aktivitas atau berolahraga seperti senam lansia, senam bugar, senam lainya dan gaya hidup sehat. Senam lansia merupakan suatu bentuk olahraga aerobik yang bermanfaat bagi lanjut usia karena dapat membantu menjaga keseimbangan tekanan darah dan penurunan tekanan, dengan melakukan kegiatan senam sesuai dengan prosedur dapat menurunkan tekanan darah. Selain itu, juga harus menghindari stress, mengurangi konsumsi garam, dan menurunkan berat badan. Kebiasaan olahraga yang tidak baik pada penderita hipertensi menyebabkan tidak terkontrolnya tekanan darah pada penderita hipertensi tersebut, untuk memotivasi penderita hipertensi melakukan olahraga, perlu dilakukan program olahraga rutin bagi penderita hipertensi oleh pihak terkait. Olahraga teratur mengurangi resiko terjadinya penyakit arteri dan mengurangi beberapa faktor resiko terhadap penyakit jantung koroner dan stroke, termasuk hipertensi, kolesterol, dan diabetes mellitus (Mufidah,2017).

\section{KESIMPULAN DAN SARAN}

Ada pengaruh senam hipertensi terhadap penurunan tekanan darah pada lansia di wilayah kerja puskesmas bontonyeleng tahun 2018. Peneliti menyarankan agar lansia yang mengalami hipertensi melakukan latihan senam secara 
efektif dan teratur serta hal lain yang mencakup dalam penatalaksanaan senam hipertensi. Selain itu juga diharapkan tidak cepat berpuas diri, walaupun telah terjadi penurunan tekanan darah, sehingga dapat meningkatkan kualitas hidup lansia. Diharapkan bagi pihak Puskesmas untuk lebih meningkatkan frekuensi pemberian senam hipertensi minimal 2-3 kali dalam seminggu untuk mendapatkan hasil yang lebih baik. 


\section{DAFTAR PUSTAKA}

Kementrian Kesehatan Republik Indonesia. (2015, Mei Selasa). Pusat Data dan Informasi.

Azizah, L. M. (2011). Keperawatan Lanjut Usia. Yogyakarta: Graha Ilmu.

Black, J. M., \& Hawks, J. H. (2014). Keperawatan Medikal Bedah. Singapore: Elsevier.

Dharma, K. K. (2011). Metodologi Penelitian Keperawatan. Jakarta Timur: CV. Trans Info.

Herwati, \& Sartika, W. (2014). Terkontrolnya tekanan darah pada penderita hipertensi berdasarkan pola diet dan kebiasaan olahraga di Padang. Jurnal kesehatan masyarakat.

Hidayat, A. A. (2009). Metode Penelitian Keperawatan dan Teknik Analisis Data. Jakarta: Salemba Medika.

Irfansyah, M. N., Herawati, \& Dian, N. (2015). Senam Lansia Terhadap Penurunan Tekanan Darah Pada Lansia Dengan Hipertensi. Senam Lansia Terhadap Penurunan TD.

Jatihningsih, K., Sudaryanto, A., \& Betty, F. (2015). PENGARUH SENAM LANSIA TERHADAP TEKANAN DARAH PADA LANJUT USIA DENGAN HIPERTENSI DI POSYANDU LANJUT USIA DI DESA WOTGALE SUKOHARJO.

Kementrian Kesehatan RI. (2014). Pusat Data dan Informasi Kementrian Kesehatan RI. InfoDATIN.

Khotimah. (2013). Stress sebagai faktor terjadinya peningkatan tekanan darah pada penderita hipertensi. Jurnal Eduhealth.

Mamahit, M. L., Mulyadi, \& Onibala, F. (2017). Hubungan Pengetahuan
Tentang Diet Garam Dengan Tekanan Darah Pada Lansia di Puskesmas Bahu Kota Manado. Ejoernal Keperawatan.

Manangkot, M. V., Sukawana, W., \& Witarsa, M. S. (2016). Pengaruh Senam Lansia Terhadap Keseimbangan Tubuh Pada Lansia Di Lingkungan Dajan Bingin Sading. Jurnal Keperawatan COPING NERS.

Mufidah, K., \& Ernawati. (2017). PENERAPAN SENAM HIPERTENSI UNTUK MENURUNKAN TEKANAN DARAH PADA PASIEN HIPERTENSI PADA KELUARGA TN.S PADA NY.K DI WILAYAH PUSKESMAS GOMBONG II.

Nasrullah, D. (2016). Buku Ajar Keperawatan Gerontik. Jakarta Timur: CV.TRANS INFO MEDIA.

Notoatmodjo, S. (2012). Metodologi Penelitian. Jakarta: PT RINEKA CIPTA.

Ode, s. L. (2012). Asuhan Keperawatan Gerontik. Yogyakarta: Nuha Medika.

Pamungkas, W., Aji, B., Isnaeni, Y., \& Sugiyanto. (2015). Pengaruh senam lansia terhadap tekanan darah pada lansia penderita hipertensi di posyandu lansia Dusun Banaran 8 Playen Gunungkidul .

Purnama, D. S., \& Prihartono, N. A. (2013). Prevalensi Hipertensi dan Faktor-Faktor Yang Berhubungan dengan Kejadian Hipertensi di Posyandu Lansia Wilayah Kecamatan Johar Baru Jakarta Pusat. Prevalensi Hipertensi.

Riskesdas. (2013). Badan Penelitian dan Pengembangan kesehatan 
kementrian Kesehatan RI. Riset

Kesehatan Dasar.

Sastroasmoro, S. (2014). Dasar-Dasar

Metodologi Penelitian klinis.

Jakarta: CV.Agung Seto.

Sugiyono. (2012). Metode Penelitian

Kuantitatif Kualitatif dan $R \& D$.

Bandung: Alfabeta.

Sugiyono. (2014). STATISTIK untuk

PENELITIAN. Bandung:

ALFABETA.

Sunkudon, M. C., Palandeng, H., \& Kallo, V. (2015). Pengaruh senam lansia terhadap stabilitas tekanan darah pada kelompok lansia GMIM Anugerah di Desa Tumaratas Kec.Langoang Barat Kab.Minahasa . Ejoernal Keperawatan .

Suprapto, I. H. (2014). Menu Ampuh Atasi Hipertensi. Yogyakarta: NSTEBOOK.

Susanto. (2010). CEKAL (Cegah dan tangka) penyakit modern.

Yogyakarta: C.V Andi offest.

Syamsuddin, Muriyati, Asnidar, \& Sumarni. (2015). Pedoman praktis metodologi penelitian internal. Ponorogo: CV. Wade group.

Tempo.co. (2018, April Kamis). 31 Persen Penduduk Indonesia Mengidap Hipertensi. Tempo.co.

Udjianti, W. J. (2013). Keperawatan Kardiovaskuler. Jakarta: Salemba Medika. 
Tabel 1

Distribusi Karakteristik Responden Di Wilayah Kerja Puskesmas Bontonyeleng Kabupaten Bulukumba

\begin{tabular}{ccc}
\hline Jenis Kelamin & Frequency & $\%$ \\
\hline Laki-Laki & 9 & 30,0 \\
Perempuan & 21 & 70,0 \\
\hline Total & 30 & 100,0 \\
\hline Umur & Frequency & $\%$ \\
\hline Usia Pertengan & 21 & 70,0 \\
Lanjut Usia & 9 & 30,0 \\
\hline Total & 30 & 100,0 \\
\hline Pendidikan & Frequency & $\%$ \\
\hline Tidak Sekolah & 6 & 20,0 \\
SD & 15 & 50,0 \\
SMP & 5 & 16,7 \\
SMA & 2 & 6,7 \\
S1 & 2 & 6,7 \\
\hline Total & 30 & 100,0 \\
\hline Pekerjaan & Frequency & $\%$ \\
\hline Ibu Rum Tangga & 18 & 60,0 \\
Petani & 8 & 26,7 \\
Wiraswasta & 2 & 6,7 \\
Guru & 2 & 6,7 \\
\hline Total & 30 & 100,0 \\
\hline
\end{tabular}

Tabel 2

Distribusi Frekuensi Tekanan Darah Sistol Sebelum dan setelah Senam di Wilayah Kerja Puskesmas Bontonyeleng Kabupaten Bulukumba

\begin{tabular}{ccc}
\hline Tekanan Darah sebelum Senam & Frequency & $\%$ \\
\hline Tinggi & 30 & 100,0 \\
Normal & - & - \\
\hline Total & 30 & 100.0 \\
\hline Tekanan Darah setelah Senam & Frequency & $\%$ \\
\hline Tinggi & 8 & 26,7 \\
Normal & 22 & 73,3 \\
\hline Total & 30 & 100.0 \\
\hline
\end{tabular}


Tabel 3

Distribusi Frekuensi Tekanan Darah Diastol sebelum dan setelah Senam di Wilayah Kerja Puskesmas Bontonyeleng Kabupaten Bulukumba

\begin{tabular}{ccc}
\hline Tekanan Darah & Frequency & $\%$ \\
\hline Tinggi & 29 & 96,7 \\
Normal & 1 & 3,3 \\
\hline Total & 30 & 100.0 \\
\hline Tekanan Darah & Frequency & $\%$ \\
\hline Tinggi & 5 & 16,7 \\
Normal & 25 & 83,3 \\
\hline Total & 30 & 100.0 \\
\hline
\end{tabular}

Tabel 4

Pengaruh Tekanan Darah Sistolik dan diastole Pada Lansia Sebelum dan Setelah Senam di Wilayah Kerja Puskesmas Bontonyeleng

\begin{tabular}{|c|c|c|c|c|c|c|c|}
\hline \multirow{3}{*}{ Tekanan Darah Sistol } & \multicolumn{4}{|c|}{ Hipertensi } & \multirow{2}{*}{\multicolumn{2}{|c|}{ Total }} & \multirow{3}{*}{$P$} \\
\hline & \multicolumn{2}{|c|}{ Tinggi } & \multicolumn{2}{|c|}{ Normal } & & & \\
\hline & $\mathrm{N}$ & $\%$ & $\mathrm{~N}$ & $\%$ & $\mathrm{~N}$ & $\%$ & \\
\hline Pretest Senam & 30 & $100 \%$ & 0,0 & $0,00 \%$ & 30 & 100 & 0000 \\
\hline Postest Senam & 8 & $26,7 \%$ & 22 & $73,3 \%$ & 30 & 100 & 0.000 \\
\hline \multirow{3}{*}{ Tekanan Darah Diastol } & \multicolumn{4}{|c|}{ Hipertensi } & \multirow{2}{*}{\multicolumn{2}{|c|}{ Total }} & \\
\hline & \multicolumn{2}{|c|}{ Tinggi } & \multicolumn{2}{|c|}{ Normal } & & & $P$ \\
\hline & $\mathrm{N}$ & $\%$ & $\mathrm{~N}$ & $\%$ & $\mathrm{~N}$ & $\%$ & \\
\hline Pretest Senam & 29 & 96,7 & 1 & 3,3 & 30 & 100 & 000 \\
\hline Postest Senam & 5 & 16,7 & 25 & 83,3 & 30 & 100 & 0.000 \\
\hline
\end{tabular}

